\title{
Identifikasi masalah kesehatan masyarakat di Desa Banguntapan melalui Data Program Indonesia Sehat Pendekatan Keluarga (PIS-PK)
}

\section{Solikhah Solikhah', Fatma Nuraisyah², Rochana Ruliyandari3 ${ }^{3}$ Putri Rizkika', Astri Widyastuti ${ }^{5}$, Swastika Tri Pertiwi ${ }^{6}$, Raras Pinastiti7, Maya Kusuma Dewi ${ }^{8}$, Tri Wahyuni9, Mita Malinda ${ }^{10}$, Debi Tara Dipa11}

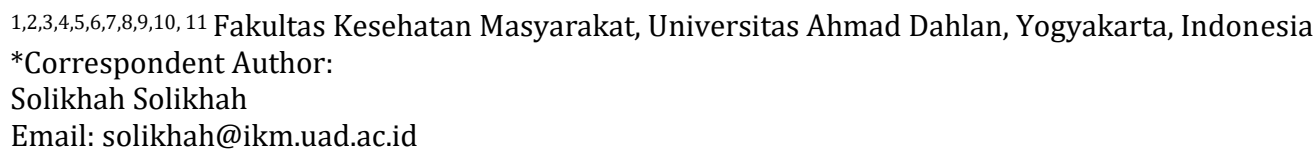

Noncommunicable diseases and chronic diseases, such as stroke, hypertension and diabetes mellitus has widely founded in Yogyakarta. In order to, the government has developed a health promotion strategy is the healthy Indonesia through a family program approach or Program Indonesia Sehat dengan Pendekatan Keluarga (PIS-PK). The study aimed to analysis determinant factors of public health problems, to obtain of the health situation and public health service in Ponegaran Hamlet, Banguntapan, Bantul. Descriptive research used to interview instruments as 149 respondents. The analysis method used to determine the priority of health problems is Urgency, Seriousness, Growth(USG). Base on three indicators of PIS-PK which were the main problems were the number of family members who smoker (53\%), hypertension who did not take regular medication $(71 \%)$ and health insurance $(34 \%)$. This is an open-access article under the CC-BY-SA license.
Keywords
Identifikasi masalah Identifika

Kesehatan masyarakat

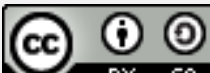

\section{Pendahuluan}

Penyakit tidak menular mengalami peningkatan secara signifikan di seluruh dunia. Selain kanker dan penyakit jantung koroner, merokok juga menjadi masalah kesehatan. Kondisi kesehatan masyarakat semakin kompleks ini juga ditunjukan dengan prevalensi penyakit dan faktor risiko yang bervariasi dan semakin meningkat. Masalah kesehatan masyarakat yang menjadi prioritas penyakit tidak menular yaitu hipertensi, diabetes melitus, kanker, penyakit paru obstruktif kronik dan merokok. Angka kematian yang diakibatkan oleh merokok terus meningkat dari (41,75\%) tahun 1995 menjadi (59,7\%) di tahun 2007[1, 2].

Penyakit tidak menular secara nasional dapat dikatakan mengalami peningkatan terlihat dari prevalensi kanker $(1,4 \%)$, batu ginjal $(0,6 \%)$, stroke $(25,7 \%)$, diabetes melitus $(1,5 \%)$, dan perokok 21,2\% pada tahun 2018 di Indonesia. Faktor risiko yang dapat menyebabkan seseorang 
mengalami penyakit tidak menular yaitu merokok, kurang aktifitas fisik, pola makan tidak sehat, obesitas, darah tinggi, gaya hidup, dan prediabetes [3].

Program ke-5 yang sudah dilaksanakan dari Nawacita yaitu Program Indonesia Sehat (PIS) dengan tujuan meningkatkan kualitas hidup masyarakat di Indonesia. Selanjutnya, PIS merupakan program utama pembangunan kesehatan kemudian direncanakan pencapaiannya melalui Rencana Strategis Kementerian Kesehatan tahun 2015-2019. Selanjutnya, ditetapkan melalui Keputusan Menteri Kesehatan RI Nomor HK.02.02/Menkes/52/2015 dengan sasaran yaitu meningkatkan derajat kesehatan dan status gizi masyarakat melalui upaya kesehatan dan pemberdayaan masyarakat. Dalam pelaksanaan PIS ada 3 pilar utama yaitu: penerapan paradigma sehat, penguatan pelayanan kesehatan, dan pelaksanaan Jaminan Kesehatan Nasional (JKN)[4].

Selain Program Indonesia Sehat, ada pula program Germas atau Gerakan Masyarakat Hidup Sehat (GMHS) dan Konsep Pendekatan Keluarga. Pendekatan keluarga adalah salah satu cara petugas kesehatan ditingkat puskesmas untuk meningkatkan jangkauan sasaran atau meningkatkan akses pelayanan kesehatan di wilayah kerjanya. Sehingga program yang dilaksanakan oleh petugas puskesmas dapat terintegrasi perorangan, mengenali masalahmasalah kesehatan masyarakat dan Perilaku Hidup Bersih dan Sehat (PHBS) dan permasalahan kesehatan yang dihadapi keluarga secara lebih detail[5, 6].

Derajat kesehatan keluarga sangat ditentukan oleh Perilaku Hidup Bersih dan Sehat dari keluarga dalam keseharian. Poin utama dari pengembangan keluarga adalah memperdayakan keluarga agar mampu mengimplementasikan PHBS. Perilaku Hidup Bersih dan Sehat adalah sekumpulan perilaku yang diimplementasikan atas dasar kesadaran dari hasil pembelajaran yang menjadikan seseorang, keluarga, kelompok, atau masyarakat mampu menolong dirinya sendiri dan berperan aktif dalam mewujudkan kesehatan masyarakat[7].

Berdasarkan data, pasien rawat jalan dan inap di RS Panembahan Senopati Bantul kasus tertinggi yaitu hipertensi untuk rawat jalan sebanyak 19.134 kasus dan 887 kasus untuk rawat inap tahun 2016[8]. Hal tersebut dapat menjadi indikasi bahwa keluarga sehat belum memenuhi standar PIS-PK. Sehingga diperlukan upaya penelusuran mendalam faktor penyebab tingginya kasus penyakit tidak menular melalui program PIS-PK. Dengan adanya program PIS-PK, dapat mengetahui indikator keberhasilan upaya membina PBHS di keluarga dalam menciptakan masyarakat sehat. Oleh karena itu, indikator keluarga sehat dapat digunakan sebagai indikator PHBS. Dalam rangka pelaksanaan PIS-PK, dua belas indikator utama yang telah disepakati dari pemerintah untuk penilaian status kesehatan sebuah keluarga. Tujuan dari penelitian ini adalah untuk mengetahui status kesehatan masyarakat melalui program indikator program PIS-PK di Desa Banguntapan. 


\section{Metode}

Jenis penelitian ini adalah penelitian deskriptif kuantitatif yang dilaksanakan di Dusun Ponegaran RT 08 RW 07 Desa Banguntapan pada bulan April sampai dengan Juli 2019. Populasi penelitian yaitu warga desa yang menetap lebih dari 6 bulan sejak pengambilan data di Desa Banguntapan. Selanjutnya, Teknik sampling yang digunakan penelitian ini yaitu random sampling. Jumlah populasi yang terdapat di lokasi penelitian sebanyak 200 orang dengan besar sampel sebanyak 149 orang. Penelitian ini menggunakan instrumen berupa kuesioner. Kuesioner ini mengenai pertanyaan terkait 12 indikator PIS-PK. Analisis yang akan digunakan adalah analisis penentuan masalah prioritas dengan metode Urgency, Seriousness, Growth (USG). Indikator nilai yang digunakan yaitu skala likert dengan penilaian skoring yaitu $5=$ sangat besar; 4=besar; 3=sedang; $2=$ kecil; 1 = sangat kecil, dimana total nilai paling tinggi akan menjadi prioritas masalah serta nilai facilititate setelah itu dilakukan analisis univariat pada variabel yang dianggap sebagai prioritas.

\section{Hasil dan Pembahasan}

Berdasarkan hasil rerata yang diperoleh bahwa nilai total merokok merupakan yang paling tinggi yaitu 18, sehingga merokok menjadi prioritas pertama masalah kesehatan masyarakat. Dari indicator anggota keluarga yang merokok, nilai rumah tangga yang memiliki anggota keluarga yang aktif merokok adalah 43,33\%. Bagi sebagian masyarakat di Desa Banguntapan, Kecamatan Banguntapan, Kabupaten Bantul, merokok sudah menjadi suatu kebiasaan. Jika dikaitkan dengan data status kesehatan masyarakat Yogyakarta, kebiasaan merokok ini memberi implikasi terhadap tingginya jumlah penderita penyakit tidak menular dan penyakit kronis seperti kanker, batu ginjal, stroke, hipertensi , diabetes mellitus, karena merokok berkontribusi terhadap penyakit-penyakit tersebut [9].

Kepala keluarga yang menjadi perokok aktif menjadi faktor yang sangat berpengaruh terhadap perilaku anggota keluarga lainnya. Artinya, perilaku merokok itu terpicu dari kepala keluarga atau anggota keluarga serta lingkungan sekitarnya yang berperilaku perokok aktif. Situasi serta kondisi lingkungan ikut berperan menjadi faktor pendukung perubahan perilaku dari pasif merokok menjadi perokok aktif misalkan ajakan orang lain, melihat, atau ingin coba-coba sehingga timbul keinginan untuk merokok. [13]. Permasalahan hidup seperti faktor stres dan lingkungan juga dapat membuat seseorang mempertahankan perilaku merokok. Selain itu, perokok aktif kebanyakan memiliki sikap negatif dimana seseorang menganggap bahwa kebiasaan merokok tidak berbahaya walaupun sudah mengetahui risiko menjadi perokok aktif. 
Prioritas masalah kesehatan yang dialami keluarga di Desa Banguntapan adalah seperti pada Tabel 1.

Tabel 1. Penentuan Prioritas Masalah Berdasarkan nilai Urgency, Seriousness, Growth, dan Facilitate.

\begin{tabular}{|c|c|c|c|c|c|c|c|}
\hline Indikator & $\begin{array}{c}\text { Nilai } \\
\text { keluarga } \\
(\%)\end{array}$ & $\begin{array}{l}\text { Nilai } \\
\text { Urgency }\end{array}$ & $\begin{array}{c}\text { Nilai } \\
\text { Seriousness }\end{array}$ & $\begin{array}{l}\text { Nilai } \\
\text { Growth }\end{array}$ & $\begin{array}{c}\text { Nilai } \\
\text { Facilititate }\end{array}$ & $\begin{array}{l}\text { Nilai } \\
\text { Total }\end{array}$ & Prioritas \\
\hline $\begin{array}{l}\text { Anggota Keluarga Ada } \\
\text { yang Merokok* }\end{array}$ & 43,33 & 5 & 5 & 5 & 3 & 18 & 1 \\
\hline $\begin{array}{l}\text { Penderita Hipertensi } \\
\text { Melakukan Pengobatan } \\
\text { Secara Teratur* }\end{array}$ & 83,33 & 3 & 4 & 4 & 4 & 15 & 2 \\
\hline $\begin{array}{l}\text { Keluarga Sudah } \\
\text { Menjadi Anggota JKN* }\end{array}$ & 60 & 4 & 4 & 4 & 2 & 14 & 3 \\
\hline $\begin{array}{l}\text { Keluarga Mempunyai } \\
\text { Akses Sarana Air } \\
\text { Bersih }\end{array}$ & 100 & 4 & 4 & 3 & 2 & 13 & 4 \\
\hline $\begin{array}{l}\text { Keluarga Mempunyai } \\
\text { Akses dan } \\
\text { Menggunakan Jamban } \\
\text { Sehat }\end{array}$ & 100 & 4 & 4 & 3 & 2 & 13 & 5 \\
\hline $\begin{array}{l}\text { Keluarga Mengikuti } \\
\text { Program KB }\end{array}$ & 70,27 & 4 & 4 & 3 & 2 & 13 & 6 \\
\hline $\begin{array}{l}\text { Ibu Melakukan } \\
\text { Persalinan di Fasilitas } \\
\text { Kesehatan }\end{array}$ & 90 & 3 & 3 & 2 & 4 & 12 & 7 \\
\hline $\begin{array}{l}\text { Bayi Mendapat } \\
\text { Imunisasi Dasar } \\
\text { Lengkap }\end{array}$ & 91,67 & 3 & 2 & 2 & 3 & 10 & 8 \\
\hline $\begin{array}{l}\text { Bayi Mendapatkan ASI } \\
\text { Eksklusif }\end{array}$ & 91,67 & 3 & 2 & 2 & 3 & 10 & 9 \\
\hline $\begin{array}{l}\text { Penderita TB Paru } \\
\text { Mendapatkan } \\
\text { Pengobatan Sesuai } \\
\text { Standar }\end{array}$ & 100 & 3 & 2 & 2 & 2 & 9 & 10 \\
\hline $\begin{array}{l}\text { Balita Dipantau } \\
\text { Pertumbuhannya }\end{array}$ & 87,5 & 2 & 2 & 2 & 2 & 8 & 11 \\
\hline $\begin{array}{l}\text { Penderita Gangguan } \\
\text { Jiwa Mendapatkan } \\
\text { Pengobatan dan Tidak } \\
\text { Ditelantarkan }\end{array}$ & 100 & 2 & 2 & 2 & 2 & 8 & 12 \\
\hline
\end{tabular}

*) Nilai rerata masalah kesehatan masyarakat dengan Indikator PIS-PK

Berdasarkan hasil penghitungan skor dengan metode USG, urutan kedua adalah permasalahan hipertensi $(83,33 \%)$. Hipertensi merupakan dampak nyata dari gaya hidup yang tidak sehat diantaranya konsumsi makanan, adanya kebiasaan merokok, tidak melakukan aktifitas fisik 
minimal 150 menit per minggu secara teratur, dan tidak dapat mengendalikan stres [16, 17]. Masalah kesehatan pada penderita hipertensi di desa Banguntapan adalah perilaku ketidakpatuhan berobat teratur. Pengontrolan rutin tekanan darah secara teratur dan melibatkan komunitas masyarakat akan sangat membantu mencegah penderita hipertensi dari bahaya lebih lanjut misalkan penyakit jantung, stroke dan lain lain[18], [19].

Prioritas masalah urutan ketiga adalah masalah Jaminan Kesehatan Nasional (JKN). Distribusi frekuensi keluarga yang belum menjadi anggota JKN (34\%). Belum meratanya distribusi dikarenakan tidak meratanya infrastuktur tiap wilayah menjadikan semua warga belum mendapatkan JKN secara menyeluruh atau kurangnya keingintahuan warga untuk mencari informasi terkait manfaat dari JKN [20-23].

Berikut adalah hasil identifikasi masalah dengan USG yang ditampilkan dalam urutan prioritas masalah dari USG seperti terlihat pada Tabel 2:

Tabel 2 Sebaran masalah kesehatan pada keluarga di Dusun Ponegaran

\begin{tabular}{lll}
\hline Masalah kesehatan & $n$ & $\begin{array}{l}\text { Presentase } \\
(\%)\end{array}$ \\
\hline $\begin{array}{l}\text { Anggota keluarga yang Merokok (usia >15 } \\
\text { tahun) }\end{array}$ & \\
$\quad$ Merokok & 79 & 53,0 \\
Tidak merokok & & \\
\hline $\begin{array}{l}\text { Penderita hipertensi yang melakukan } \\
\text { pengobatan secara teratur }\end{array}$ & & \\
Pengobatan teratur & 43 & 29,0 \\
$\quad$ Pengobatan tidak teratur & 106 & 71,0 \\
\hline Anggota keluarga yang sudah memiliki JKN & & \\
Ya & 98 & 66.0 \\
Tidak & 51 & 34,0 \\
\hline
\end{tabular}

Manusia merupakan mahluk sosial, dimana manusia tidak dapat hidup sendiri, berkomunikasi secara interaktif serta melakukan relasi yang baik sangat dibutuhkan untuk perkembangan sosial dan moral seseorang. Sehingga, situasi lingkungan sosial sangat berperan terhadap kepercayaan dan perhatian individu pada perokok aktif maupun pasif. Lingkungan sosial dengan kondisi pergaulan merokok didalam rumah atau diluar rumah, cenderung akan mempengaruhi perilaku individu ataupun kepala keluarga untuk ditiru dibandingkan dengan situasi lingkungan sosial yang baik tidak berperilaku merokok di rumah ataupun diluar rumah. Perokok aktif yang terpapar oleh iklan rokok dapat disimpulkan bahwa iklan bukan menjadi faktor utama untuk tetap berperilaku merokok. Namun, seseorang dapat terpengaruh dari seringnya terpapar dengan hal-hal yang berkaitan dengan merokok misalkan lingkungan perokok Identifikasi masalah kesehatan masyarakat ....(Solikhah Solikhah, Fatma Nuraisyah, dkk) 
aktif. Maka, perilaku merokok menjadi kebiasaan sehari-hari[2]. Iklan rokok bukan menjadi satusatunya faktor pemicu seseorang untuk merokok [10]. Selain, iklan rokok yang dapat mempengaruhi perilaku seseorang menjadi perokok aktif, namun ada faktor lain yang berperan aktif dalam perubahan perilaku manusia misalkan diri sendiri maupun lingkungan [11]. Lingkungan sekitar sangat berpengaruh terhadap perilaku merokok apabila seseorang lebih sering beraktifitas dan menghabiskan waktu di lingkungan perokok aktif, maka akan timbul keinginan untuk mencoba walaupun tidak terpapar dengan iklan rokok [12]"

Disamping itu, hal yang sangat berpengaruh terhadap perubahan perilaku adalah tekanan mental/tekanan kerja dari lingkungan sekitar. Seorang perokok pasif bisa berubah menjadi perokok aktif meskipun tinggal di lingkungan perokok pasif. Hal tersebut terjadi akibat dari pengaruh beban pikiran yang membuat seseorang stres sehingga tekanan yang dialami menimbulkan rasa tidak nyaman dengan suatu keadaan, merasa marah, frustasi, rasa sedih yang berlebihan akhirnya akan mencari ketenangan atau pelarian dari beban pikiran atau tekanan mental[14,15]. Ketika seseorang mengalami stress serta tidak mendapatkan kenyamanan dari lingkungan ataupun orang terdekat, sehingga dapat dikatakan bahwa seseorang bisa berubah tidak dari lingkungan tempat tinggalnya, namun bisa dari pikiran sendiri [12].

\section{Kesimpulan}

Dari hasil identifikasi masalah dapat disimpulkan masih banyak anggota rumah tangga yang memiliki jumlah kasus perokok aktif didalam rumah, selain itu juga ditemukan masih banyak penderita penyakit hipertensi yang tidak melaksanakan pengobatan secara rutin di pelayanan kesehatan bagi serta masyarakat, serta belum terdaftar sebagai anggota Jaminan Kesehatan Nasional. Indikator PIS-PK dapat disosialisasikan kembali kepada masyarakat dan perlu dilakukan monitoring terhadap masing-masing indikator secara berkala dengan melibatkan kader-kader dan juga tokoh-tokoh masyarakat setempat sehingga wawasan masyarakat terhadap indikator keluarga sehat dapat meningkat. Kesadaran terhadap indikator keluarga sehat diharapkan dapat lebih mendorong masyarakat untuk berperilaku hidup bersih dan sehat sehingga keluargakeluarga yang sehat dapat tinggal dalam lingkungan yang sehat. Kumpulan keluarga-keluarga sehat dan lingkungan sehat dapat menjadi masyakat yang sehat.

\section{Ucapan Terima kasih}

Terimakasih kepada Kepala Puskesmas Banguntapan, dekan FKM dan ketua prodi Kesehatan Masyarakat UAD, serta semua pihak yang telah membantu dalam pelaksanaan penelitian. 


\section{Konflik Kepentingan}

Tidak ada

\section{Referensi}

1. Moeloek NF. Indonesia national health policy in the transition of disease burden and health insurance coverage. Medical Journal of Indonesia. 2017 May 16;26(1):3-6.

2. Collins D, Hafidz F, Mustikawati D. The economic burden of tuberculosis in Indonesia. Int J Tuberc Lung Dis. 2017 01;21(9):1041-8.

3. Diniawati E, Wibowo A. The Economic Burden and Non-Adherence Tuberculosis Treatment in Indonesia: Systematic Review. KLS. 2019 Feb 28;4(10):17.

4. Nadjib M, Setiawan E, Putri S, Nealon J, Beucher S, Hadinegoro SR, et al. Economic burden of dengue in Indonesia. PLoS Negl Trop Dis. 2019 Jan 10;13(1).

5. Haryanto B. Indonesia Dengue Fever: Status, Vulnerability, and Challenges. In: Current Topics in Tropical Emerging Diseases and Travel Medicine. 2018.

6. Harapan H, Michie A, Mudatsir M, Sasmono RT, Imrie A. Epidemiology of dengue hemorrhagic fever in Indonesia: analysis of five decades data from the National Disease Surveillance. BMC Research Notes. 2019 Jun 20;12(1):350.

7. Kemenkes RI. Riset Kesehatan Dasar (Riskesdas 2013).Jakarta, Kementerian Kesehatan RI; 2013.

8. Ni'mah K, Nadhiroh SR. Faktor yang berhubungan dengan kejadian Stunting pada balita A. Media Gizi Indonesia. 2016 Dec 22;10(1):13-9.

9. Kemenkes RI. Rencana Strategis Kementerian Kesehatan tahun 2015-2019. Jakarta: Kementerian Kesehatan RI; 2015.

10. Sirait AM, Pradono Y, Toruan IL. Perilaku merokok di Indonesia. Buletin Penelitian Kesehatan. 2002;30(3 Sep).

11. Cahyo K, Wigati PA, Shaluhiyah Z. Rokok, Pola Pemasaran dan Perilaku Merokok Siswa SMA/Sederajat di Kota Semarang. MEDIA KESEHATAN MASYARAKAT INDONESIA. 2012;11(1):75-85.

12. Rochayati AS, Hidayat E. Faktor-Faktor Yang Mempengaruhi Perilaku Merokok Remaja di Sekolah Menengah Kejuruan Kabupaten Kuningan. Jurnal Keperawatan Soedirman. 2015 Mar 1;10(1):1-11.

13. Wiryanatha MA, Ani LS. PERILAKU MEROKOK PADA SISWA LAKI-LAKI SEKOLAH MENENGAH PERTAMA DI WILAYAH KERJA PUSKESMAS SUKASADA II. E-Jurnal Medika Udayana. 2014;3(3).

14. Rahmadi A, Lestari Y, Yenita Y. Hubungan Pengetahuan dan Sikap Terhadap Rokok Dengan Kebiasaan Merokok Siswa SMP di Kota Padang. Jurnal Kesehatan Andalas. 2013 Jan 1;2(1):258.

15. Park S. Smoking and adolescent health. Korean J Pediatr. 2011 Oct;54(10):401-4. 
16. Wiener RC, Shockey AKT, Morgan SK. Adolescent Light Cigarette Smoking Patterns and Adult Cigarette Smoking. Advances in Epidemiology. 2016;27990461.

17. Moylan S, Gustavson K, Karevold E, Øverland S, Jacka FN, Pasco JA, et al. The Impact of Smoking in Adolescence on Early Adult Anxiety Symptoms and the Relationship between Infant Vulnerability Factors for Anxiety and Early Adult Anxiety Symptoms: The TOPP Study. PLOS ONE. 2013 May 16;8(5):e63252.

18. Suoth M, Bidjuni H, Malara R. Hubungan gaya hidup dengan kejadian hipertensi di Puskesmas Kolongan Kecamatan Kalawat Kabupaten Minahasa Utara. JURNAL KEPERAWATAN 2014 Feb $282(1)$.

19. Weber MA, Schiffrin EL, White WB, Mann S, Lindholm LH, Kenerson JG, et al. Clinical Practice Guidelines for the Management of Hypertension in the Community. The Journal of Clinical Hypertension. 2014 Jan 1;16(1):14-26.

20. Hussain MA, Mamun AA, Reid C, Huxley RR. Prevalence, Awareness, Treatment and Control of Hypertension in Indonesian Adults Aged $\geq 40$ Years: Findings from the Indonesia Family Life Survey (IFLS). PLOS ONE. 2016 Aug 24;11(8):e0160922.

21. Mboi N. Indonesia: On the Way to Universal Health Care. Health Systems \& Reform. 2015 Feb 17;1(2):91-7.

22. Pisani E, Olivier Kok M, Nugroho K. Indonesia's road to universal health coverage: a political journey. Health Policy Plan. 2017 Mar 1;32(2):267-76.

23. Kesuma ZM, Chongsuvivatwong V. Utilization of the Local Government Health Insurance Scheme (JKA) for Maternal Health Services Among Women Living in Underdeveloped Areas of Aceh Province, Indonesia. Asia Pac J Public Health. 2015 Apr 1;27(3):348-59. 